\title{
IMPROVING THE TWELFTH GRADE STUDENTS' VOCABULARY MASTERY THROUGH STORY TELLING TECHNIQUE IN SMA SANTO PETRUS MEDAN
}

\author{
Hema M Simbolon, Fiber Yun Ginting, Novalina Sembiring \\ Catholic University of Saint Thomas \\ Email : novalina_sembiring@ust.ac.id
}

\begin{abstract}
Vocabulary mastery is the basic language aspect that must be mastered before mastering English skill. The more words the students learn, the more they can understand and express their idea in that language. When they have inadequate vocabulary, they can say little things because they do not know how to say it in that language. That is why this study was conducted in order to improve the students' vocabulary mastery. Storytelling technique can help students for remembering or mastering vocabulary. The objectives of this study are to find out whether Storytelling technique can improve the students' English vocabulary mastery and find out the students' responses after being taught by using Storytelling technique. The subjects of this study were the twelfth grade students of SMA Santo Petrus Medan. In conducting this study the writer used Classroom Action Research (CAR) as the method of the study. Tests were used to gather the quantitative data. In addition, field notes and observation sheet were used to gather qualitative data. Based on the finding of this study, it showed in pre-test only 4 students (16\%) who passed KKM (Mastery Minimum Criterion) and in post-test 22 students $(88 \%)$. The result of this study revealed that there was a significant improvement of the students' achievements in the pre-test and in the post-test. It could be seen from the improvement of the students' mean score 59.52 in pre-test to 80.48 in post-test. Furthermore, the students were interested in Storytelling technique. The analysis of the questionnaire showed that most of students agree to learn vocabulary by using Storytelling technique. It could be seen from the table, it showed that total of agree $47.2 \%$. Therefore, Storytelling technique was an effective technique in helping students to improve their vocabulary mastery.
\end{abstract}

Keywords: vocabulary mastery, storytelling technique

\section{INTRODUCTION}

English is an international language which is spoken almost all over the world. In the global era, English plays an important role as communication used in many things of life, such as education, politics, science, technology and many others. Therefore, people should understand and master English in order to gain knowledge, information and technology. There are many components in a language and one of them is vocabulary. Vocabulary is a stock of word that has its own meaning, it can be more than one. Krashen (1981:12) states that vocabulary is a basis to communicate and also important for the acquisition process. 
Vocabulary also as the basic aspect of English to support listening, speaking, reading and writing. Without mastering the vocabulary, someone will get difficulty in communicating.

Vocabulary includes collection of words. The words are known not only as individual words, but also as a group of words that have meaning. This is the reason why learners must have some degree of vocabulary. In reality, teaching English for senior high school students are not easy. There are still many problems which occur during the process.

Based on the writer's experience through PPL (Field experience program) in class XI.IS 2 of SMA Santo Petrus Medan, it was found that the students still had difficulties in English especially in learning vocabulary. The first problem was the students have limited vocabulary. The second problems was students cannot communicate his thoughts and ideas clearly both oral and written. The students were also discouraged to find out the meaning of the word in dictionary.

To solve the problems, the writer chooses Storytelling technique as her technique. Storytelling is an ancient verbal art which is defined in various ways. McDury and Alterio (2003:104) state, "Storytelling is a unique human experience that enables us to convey, through the language of words, stories enable us to know real and imagined worlds and our place in them". English learning can be done by using short story, especially in improving vocabulary mastery. Stories are motivating, challenging, fun and they can develope positive attitudes. Story can make the students interested in studying English. The students might have their own imagination or fantasy and they can take moral lesson from it. At the first time when the students learn using short story, the students will have a great enthusias $m$ because the students want to know about the story.

The writer chooses this technique because some research findings showed the good results of teaching vocabulary by using Storytelling technique. The first research was conducted by Halimah (2017) entitled 'Improving the Students' Vocabulary Mastery by Using Storytelling at the Seventh Grade of SMP Ta'mirul Islam Surakarta in the Academic Year of 2016/2017'. She concluded that using Storytelling technique give a positive effect towards students' vocabulary mastery. The succes can be seen from the pre-test score was 5,4 . The post-test 1 score was 6,2 . The post-test 2 score eas 7,2. The increase of the pre-test and post-test 1 is 30 $\%$, the increase of post-test 1 to post-test 2 is $20 \%$. The students' mean score in the post-test improved from the pre-test significantly in which the improvement reached $50 \%$. It shows that there is an improvement of students' vocabulary achievement. The second one was carry out by Arisca (2008) entitled "Improving the Students' Vocabulary Mastery through Storytellingat the Eighth Grade Students of SMPN 2 Kotagajah in the Academic Year of 2007/2008". She concluded that Storytelling technique improved students' vocabulary mastery. Storytelling technique made students achievement improved in every cycle. The mean score 76.09, the higher score was 94, the lowest score was 63 which categorized as good to excellent. In conclusion, storytelling can be as problem solving in learning vocabulary. It is suggested that English teacher used Storytelling teachnique as one of alternatives technique in teaching vocabulary.

Based on the background of the study, the writer is interested in conducting a research entitled 'Improving the Twelfth Grade Students' Vocabulary Mastery 
through Storytelling Technique in SMA Santo Petrus Medan Academic Year of 2018/2019".

\section{REVIEW OF LITERATURE Vocabulary Mastery}

Vocabulary as one of the language aspects has to be learned when people are learning a language. Good mastery of vocabulary is important for anyone who learns the language used in listening, speaking, reading and writing besides grammar. A learner of the foreign language will speak fluently and accurately, write easily, or understand what he or she reads or hears if he has enough vocabulary and has a capabilty of using it accurately.

Thornburry (2002:15) states that in the most basic level, someone is said already knowing a word when he or she knowing its form and its meanings. He explains that knowing the meaning of word does not just know its dictionary meaning. It also means knowing the words commonly associated with it (collocation) as wellbas its connotation, including its register and its cultural accretions.

Hiebert and Kamil (2005:7) state that:"Vocabulary can be acquired through incidental learning. Much of a learner's vocabulary will have to be learned in the course of doing things other than explicit vocabulary learning. Repetition, richness of context, and motivation may also add to the efficacy of incidental learning of vocabulary."

Vocabulary and mastery are parts of set in learning vocabulary. Vocabulary mastery is clearly shown by learner's ability in expressing vocabulary that is known with understanding. Vocabulary mastery is the purpose of learning vocabulary, because when the learners master vocabulary they are able to use it in daily life. Further, to be able to master vocabulary, one should be able to through the degree of word knowledge. By mastering the English vocabulary the students can comprehend what a speaker or wirter conveys to them notably in oral and written communication. Mastering a word means mastering the aspects of word knowledge.

\section{Teaching Vocabulary}

Brown (2000:7) states, "Teaching is an activity in which the teacher guides and facilitates learning, gives a chance for the learners to learn, and sets the condition for learning". The teacher can help the students in gaining the knowledge by giving facilities such as tasks. By giving these tasks, the teacher lets the students study by themselves. To make the teaching and learning process run well, the teacher needs to set a good situation for the students to learn.

Teaching vocabulary has such as an important role in English as a foreign language in classroom, and it should be part of the syllabus and taught on regular base. When the learning teaching process takes places, problems would appear to the teachers. They have problems of how to teach students in order to gain satisfactory results. Teacher should prepare and find out the appropriate techniques which will be implemented to the students. Teachers need to be able to master the material in order to be understood by students, and make them interested and happy in the learning teaching process in the classroom.

Lewis and Hill (1992:102-103) state that there are some vocabulary teaching techniques as follows:

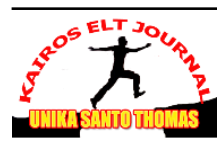


1. Contrast (Opposite/Antonyms)

Teachers can present the meaning of "empty"e by contrasing it with "full"e, "cold"e by contrasing it with "hot"e "big"e by contrasing it with "smalle, students will learn two words instead of one.

2. Synonyms

Sometimes it is helpful, particularly with a relatively unimportant word of passive vocabulary, to provide a quick synonym explanation. It is helpful if teachers say "it is similar in meaning to..." to build up in the students mind the idea that language consists of choice, that words do not mean he same as each other.

3. Enumeration

It deals with general and specific words. Teachers can say "clothes" and explain this by enumerating or listing various items.

4. Explanation

This technique can be better used with intermediate students. Expalining the meaning of a word must include explaining any fact of word use which are relevant. If teachers explain the meaning of "mate" (=friend), they have to point out that it is a colloquial word used in informal contexts and that it is more often used for males for females.

5. The Dictionary

Teachers can ask students to look up the word in the dictionary, this way provides practice in important learning skills, dictionary using.

6. Translation

It is a quick and easy way to pressent the meaning of words, but it is not without problem. It is not always easy to translate words. Besides, it may make it a bit too easy for students by discouraging them from interacting with the words. Furthermore, teachers may find it difficult to use this way with a class of different nationalities since it is not easy to translate into all the necessary languages. However, there are always some words that need to be translated and this technique can save a lot of time. If teachers do translate vocabulary, they need to exemplify the word in context so that students will not forget is easily.

7. In context

If the word occurs in a text or passage, the meaning can often be deduced when the other words in the sentence are already known. This deductive process applies particularly to the use of reading passage or stories, whether taped, read, or told.

8. Word games

There are a large variety of these and they are useful for practicing and revising vocabulary after it has been introduced. For example, crossword puzzle and scrabble.

From those various technique. There are several ways in teaching vocabulary like contrast (opposites/Antonyms), synonyms, the dictionary, tra nslation. Those techniques can be developed by storytelling, a one of the technique that can cover those ways in teaching vocabulary. 


\section{Storytelling Technique}

Storytelling is an annual ancient verbal art which is defined in various ways. According to Taylor (2000:6) storytelling is a tale to one or more listener through voice and gesture. In oral telling, we usually repeat things more than redundancy, especially the students who have difficulty to follow teacher. Moreover, Ellis (1991:33) states that vocabularies in the story are presented in vivid and clear context and illustration to convey meaning. Both the context and amusing situation can make the vocabulary easy to remember. This is in line with Burn and Broman (1975:140) who state that storytelling is an often neglected art but one which can be learnt by persistent and patient effort. Everyone who matters this art will find the rewards worth the effort required. Taking into account the commonalities of these definitions, Storytelling is sharing ideas and experiences through words and actions to communicate.

Stories are rich materials for students to learn about the world they live in. There are so many reasons for Storytelling to students, it combines all four skills: listening, speaking, reading and writing in a meaningful context and also present grammar, vocabulary and speech. Retelling or remembering the plot of story can foster learners cognitive and social skills; cognitive activities such as identifying characters, comparing their behaviors and reactions during story and defining concepts. Stories can divided according to their content to: classical tales, animals tales or fables, adventures and romantic stories. Students in different cultures are familiar with classical tales, they know the plot, characters and ending of these kind of stories, so they can predict the unknown words. The problems which inhibit teachers from using such stories are: the length of the stories and the large amount of vocabulary. Animals tales or fables are very popular among students, especially characters that can talk and behave like human being. Adventures and romantic stories have also popular in students such as heroes and heroines who are good and kind and their enemies who are bad, ugly and nasty.

The reason of the writer choosing storytelling as a media to improve students' vocabulary mastery because children love the story, and often they are motivated to tell stories to others. Storytelling make the vocabulary easy to remember so that the children enjoy learning English and it will improve their vocabulary improvement.

\section{RESEARCH METHOD}

The research design that will be used in this study is Classroom Action Research (CAR). Nunan (1992:229) states that action research is a form of selfreflective inquiry carried out by practioner, aimed at solving problems, improving practice, or enchaning understanding. It is related to the ideas of reflective practice in the teacher as researcher. Through the Classroom Action Research (CAR), the teacher will know the problem that students faced in learning when the teacher gives treatment to the students and evaluate their achievement in learning. It is like a procedure to evaluate the successful of teaching learning process. This research design is quantitative and qualitative research. Quantitative research is use to quantify the problem by way generating numerical data or data can be transformed into useable statistic. Quantitative data uses measurable data to formulate facts and uncover pattern in reserach. Qualitative research is also used to uncover trends in thought and opinions, and dive deeper into the problem. Qualitative data are 
obtained from the observation sheet the teacher and the students, fields notes and questionnaire. Quantitative data are obtained from students' pre-test and post-test. In this data collection, the researcher needs a collaborator. A collaborator in classroom action research is person who helps the researcher to collect the data.

\section{DATA ANALYSIS \\ The Data Analysis}

There are two types of data which were analyzed to find out the result of improving students'vocabulary mastery through Storytellng technique. They are quantitative and qualitative data.

\section{Quantitative Data}

The quantitative data was taken from the test result of students, namely pretest before treatment, formative test after cycle I, and post test after the end of cycle II. The complete result of the students' score in every test can be seen from the table and the histogram of score interval and the frequency.

Based on the histogram of pre-test, the highest frequency for 49-57 is 9 students (36\%). It means that there are 9 students (36\%) who occupy in score interval 49-57. The lowest of frequency for score interval $94-100$ is zero (0\%). No students can achieve the score. Then, frequency for score interval $40-48$ is 5 students (20\%). Frequency for score 58-66 is 4 students (16\%/). Frequency for score interval 67-75 and 76-84 are 3 students (12\%). And frequency for score interval $85-93$ is 1 students $(4 \%)$.

\section{Post-test Score Interval}

Based on histogram of formative test, the highest frequency for 72-76 is 11 students (44\%). It means that there are 11 students (44\%) who occupy in score interval 72-76. The lowest of frequency for score interval 92-96 and 97-100 are 1 students (4\%). Then, frequency for score interval $77-81$ is 6 students (24\%). And frequency for score interval $82-86$ is 4 students (16\%). And frequency for score interval $87-91$ is 2 students $(8 \%)$.

From the result of the students' score, it is concluded that the students' mean score increased. The data showed that in pre-test, the students' mean score is 59.52 while the students' mean score in the formative test is 71.84 and in post-test is 80.48. Then the mode and median of the students' score in post-test are higher than formative test. It means that there is improvement of the students' vocabulary mastery by using Storytelling technique.

In this study if $70 \%$ students got $>75 \%$ on their test, it means that Storytelling technique was effective to improve students' English vocabulary mastery. The percentage of the students' achievement in vocabulary mastery was presented as follows:

In the pre-test, there are 4 students $(16 \%)$ who got score $>75$ and in the formative test there are 9 students $(36 \%)$ got score $>75$, whereas in the post-test there are 22 students $(88 \%)$ got score $>75$. From the pre-test to post-test, there was significant development of the students' vocabulary achievement from $16 \%$ to $88 \%$. Thus the percentage improvement of students who got score $>75$ from the pre-test 
(16\%) to post-test (88\%) is $72 \%$. It can be concluded that Storytelling technique could help students in improving their achievement in vocabulary mastery.

\section{Qualitative Data}

The qualitative data were taken from field notes, observations, and questionnaire. The data analysis was presented below:

\section{Field Notes}

\section{Meeting 1 (Pre-test): Saturday, August $25^{\text {th }}, 2018$}

In the first meeting, the writer met twelfth grade students of SMA Santo Petrus Medan, and the writer was accompanied by Mrs. Siregar the English teacher at the school. It was held on Saturday, August $25^{\text {th }}, 2018$ at $07.15 \mathrm{am}-08.45$ am The writer started the meeting by greeting and introducing herself to the students and explained the purpose of his coming to the school in order to conduct a research for accomplishing his Sarjana's thesis.

Before conducting the first cycle, the pre-test was given to measure how far the students' vocabulary mastery. In this occasion, the writer explained the students how to answer the questions The students just did the pre-test consisting of 25 items and was carried out for 45 minutes. When the time was up, the writer collected the test that has been done by the students. After that, the writer told the students that the writer would meet the students in the next meeting.

Cycle I

The following are the elaborations of the cycle I:

\section{Meeting 2 (Treatment I): Wednesday, August $29^{\text {th }}, 2018$}

The second meeting was beginning of the cycle I. It was held on Wednesday, August $29^{\text {th }}, 2018$ at $08.45 \mathrm{am}-10.30 \mathrm{am}$. The writer opened the class with a greeting and praying after that the writer checked the students' attendance list. Then the writer implemented brainstorming by asking the students some questions about the material to be studied. The writer explained the definition of synonims and anthonyms and also gave the examples. Then, the students were introduced to Storytelling technique. The writer asked the students to pay full attention to listening the story that the writer read and helped by the picture on projector to find out the vocabularies that related to the story. The story in this meeting is about Cinderella. In this meeting, the writer also did not manage the time all. The writer had to leave the class when time was up.

\section{Meeting 3 (Treatment II): Saturday, September $1^{\text {st }}, 2018$}

In this meeting, the writer reviewed the material. Next activity was the same as in the second meeting. The writer continued the previous lesson. The writer asked the students to memorize the previous lesson by asking some questions. The writer explained the definition of synonims and anthonyms and also gave the example. Then, the students were introduced to Storytelling technique. The writer asked the students to pay full attention to listening the story carefully that the writer read and helped by the picture on projector to find out the vocabularies that related to the story. The same story in this meeting is about Cinderella. During the teaching and learning process the students looked interested in the picture that showed. They 
were tought very hard in relating between picture and Cinderella story and also memorized the vocabularies that they didn't know. When time was up the writer together with the students made a conclusion from the material that has been given the writer.

\section{Meeting 4 (Treatment III): Wednesday, September $5^{\text {th }}, 2018$}

The fourth meeting was the last phase of cycle I. In this phase, the writer had to ensure the students' understanding by giving a test that was called formative test. Before giving the formative test, the writer asking the students some questions about the topic.

At the end of this meeting the writer gave students the formative test in order to measure their knowledge or to see their improvement about vocabularies by using Storytelling technique. The test was not same with the pre-test. But there are some tests were same. There are 25 items which was carried out for 40 minutes to choose the correct answers.

\section{Cycle II}

The following are elaborations of cycle II:

\section{Meeting 5 (Treatment IV): Wednesday, September $12^{\text {th }}, 2018$}

This meeting was the beginning of cycle II. The writer gave the students motivation to learn English. As usual the writer and the students prayed before starting the lesson. The writer reviewed this topic to clarify the previous lesson. Based on result of the formative test, the students' mean score is 71.84 and there are 9 students passed $K K M$. Thus the writer evaluate students' weakness in the previous meeting. The writer reviewed the procedures of Storytelling technique to the students. Next the writer gave the story about Beauty and The Beast as the second story. By the same procedures, the writer read the story aloud and students listening carefully and helped by picture to find vocabularies that related to the story. Then, the writer concluded all about the material. After that the writer closed the meeting by prayed and said good bye.

\section{Meeting 6 (Treatment V): Saturday, Sepember $15^{\text {th, } 2018}$}

This meeting was done on Saturday, September $15^{\text {th }}, 2018$ at $07.15 \mathrm{am}-$ $08.45 \mathrm{am}$. As usual the writer asked the students be quiet during teaching and learning so that they were more focused on material and the teacher's explanation. In this meeting, the writer asked the students to pay full attention to listening the story carefully that the writer read and helped by the picture on projector to find out the vocabularies that related to the story. The same story in this meeting is about Beauty and The Beast. During the teaching and learning process the students looked interested in the picture that showed. They were tought very hard in relating between picture and Beauty and The Beast story and also memorized the vocabularies that they didn't know. When time was up the writer together with the students made a conclusion from the material that has been given the writer.

\section{Meeting 7 (Treatment VI): Wednesday, September $19^{\text {th }}, 2018$}

The seventh meeting was the last meeting before giving a post-test or end of cycle II. The teacher explained the topic about Storytelling technique. In this meeting the material was still about Storytelling technique was title about Beauty 
and The Beast. The writer taught about the generic structure of the story as narrative text. The writer recorded the students' understanding about narrative text. Then, the writer asked about difficulties in learning process through Storytelling technique. After that, the writer told them to prepare their self in the next coming Saturday.

\section{Meeting 8 (Post-test) :Saturday, September $22^{\text {th }}, 2018$}

Meeting 8 was the last meeting for post-test. The number of questions and length of doing the post-test were same as in the pre-test and formative test. It was 25 items and carried out for 40 minutes. The field notes showed that the teaching learning process was carried out well. The students were happy and interested in learning vocabulary by applying Storytelling technique. Sometimes, the situation in the classroom was noisy, but the teaching learning process could run well from the first until the last meeting.

In other side the observation sheet 1 was filled by the collaborator. The collaborator observed the students during teaching learning process. The writer found in the cycle I there was some students who were still confused about the concept of Storytelling technique. But in observation sheet 2, not too many lack, the writer could manage the time well and also some of the students payed their full attention to the writer.

\section{Questionnaire}

The questionnaire was filled by stuedents. This questionnaire was given to the students in order to find out the students' responses, the students attitude, and the students interest during learning teaching process by using Storytelling technique. Based on the result of questionnaire (Appendix 5), the writer presented it in the table.

Table 4.6 The Questionnaire Result

\begin{tabular}{|l|l|c|c|c|c|c|c|c|c|c|c|}
\hline \multirow{2}{*}{ No } & \multirow{2}{*}{ Description } & \multicolumn{2}{|c|}{ Strongly Agree } & \multicolumn{2}{|c|}{ Agree } & \multicolumn{2}{|c|}{ Quite Agree } & \multicolumn{2}{|c|}{ Disagree } & \multicolumn{2}{|c|}{$\begin{array}{c}\text { Strongly } \\
\text { Disagree }\end{array}$} \\
\cline { 2 - 12 } & $\begin{array}{l}\text { Sum of } \\
\text { Students }\end{array}$ & $\%$ & $\begin{array}{c}\text { Sum of } \\
\text { Students }\end{array}$ & $\%$ & $\begin{array}{c}\text { Sum of } \\
\text { Students }\end{array}$ & $\%$ & $\begin{array}{c}\text { Sum of } \\
\text { Students }\end{array}$ & $\%$ & $\begin{array}{c}\text { Sum of } \\
\text { Students }\end{array}$ & $\%$ \\
\hline 1 & $\begin{array}{l}\text { Students' } \\
\text { Interest. }\end{array}$ & 5 & $20 \%$ & 17 & $68 \%$ & 1 & $4 \%$ & 2 & $8 \%$ & 0 & $0 \%$ \\
\hline 3 & $\begin{array}{l}\text { Students } \\
\text { response } \\
\text { (reaction) }\end{array}$ & 15 & $60 \%$ & 7 & $28 \%$ & 3 & $12 \%$ & 0 & $4 \%$ & 0 & $0 \%$ \\
\hline & $\begin{array}{l}\text { The } \\
\text { advantages } \\
\text { of } \\
\text { Storytelling } \\
\text { technique }\end{array}$ & 10 & $40 \%$ & 11 & $44 \%$ & 2 & $8 \%$ & 2 & $8 \%$ & 0 & $0 \%$ \\
\hline 4 & $\begin{array}{l}\text { The using of } \\
\text { Storytelling }\end{array}$ & 11 & $44 \%$ & 12 & $48 \%$ & 2 & $\%$ & 0 & $0 \%$ & 0 & $\%$ \\
\hline 5 & $\begin{array}{l}\text { Applying } \\
\text { Storytelling } \\
\text { technique in } \\
\text { classroom. }\end{array}$ & 10 & $40 \%$ & 12 & $48 \%$ & 3 & $\%$ & 0 & $0 \%$ & 0 & $0 \%$ \\
\hline
\end{tabular}

Based on the result of questionnaire, it can be concluded that the students' responses towards teaching learning process of vocabulary mastery by Storytelling technique are good because the students agree to learn vocabulary by using Storytelling technique. 


\section{Observation Sheets}

There were two observation sheets. The first observation sheet was used to observe the contribution of Storytelling and the second observation sheet was used to observe all the condition that happened during the teaching learning process. From the result of observation sheets, the writer focused on the situation of teaching learning process we could see that there was an improvement from cycle $I$ in to cycle 2 .

However, in cycle two after the students learning vocabulary by using Storytelling they feel enjoy, interested and felt entertained by the story also the class atmosphere is more fun. Based on the result of observation about responses of the students, they are interested in Storytelling technique was higher after conducting Storytelling technique. The observation sheets were attached in appendix 3.

\section{Discussion}

Storytelling technique was applied to improve the students' vocabulary mastery of twelfth grade students of SMA Santo Petrus Medan. As the collaborator, the English teacher and the writer collaboratively discussed the result of the study. They concluded that the use of Storytelling technique could be the effective way to help students in vocabulary mastery. It was shown in histogram 4.4, in which the mean score of each test improved. The mean score of pre-test was 59.52, formative test was 71.84, and post-test was 80.48. Those score showed that the second cycle was better than the first cycle. Besides that, the improvement can be seen from the observation sheet and field notes. Most of the students were more active and enthusiastic during the process of teaching and learning that started from the first to the second cycle when the technique was applied.

From the table 4.5 showed that in the formative test percentage of the students' who got score $>75$ is higher than pre-test and also in the post-test, the percentage of the students' who got score $>75$ is higher than in the formative test. It means that the students' score kept increasing after Storytelling technique was applied in learning teaching process. The students' responses towards learning teaching process of vocabulary mastery by Storytelling technique can be seen in table 4.6 in that table, from the description the students' interest is 17 students (68\%), the highest students' response is 15 students (68\%) strongly agree, the advantages of Storytelling technique is 11 students (44\%) agree, the using of Storytelling technique is 12 students $(48 \%)$ agree, and the Storytelling technique applying in classroom is 12 students (48\%) agree. Based on the result of the questionnaire, the students agree that Storytelling technique is appropriate to improve their vocabulary mastery.

In conclusion, Storytelling technique was suitable technique to improve students' vocabulary mastery because this technique helped the students to understand the material easily because the writer makes the students were interested and felt entertained with the story. This technique could help the teacher to find out the solutions of students' problem especially in improve vocabulary mastery.

\section{CONCLUSIONS} follows:

After analyzing and discussing the data, the conclusions are drawn as

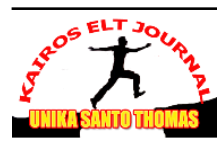


1. Improving students' English vocabulary mastery by using Storytelling technique is effective especially in SMA Santo Petrus Medan which is located at Jl. Luku 1 No. 1 Medan. After analyzing the data, it is find out that the process of teaching vocabulary mastery by using Storytelling technique could improve students' vocabulary mastery. It is proved by the improvement of the students' mean score in pre-test was 59.52, formative test was 71.84 and posttest was 80.48. The improvements of the students' mean score from the pretest until post-test increase 35.21\%. Meanwhile, the students' score percentage that passed Mastery Minimum Criterion (Kriteria Ketuntasan Minimal (KKM))from pre-test was $16 \%$, the formative test was $36 \%$, and posttest was $88 \%$. The students' score percentage continuously increased in each stage. Therefore, Storytellong technique significantly improves students' achievement in vocabulary mastery.

2. The process of teaching vocabulary by using Storytelling technique is good. It can be seen from the students' interaction during teaching learning process, most of the students were interested and felt entertained of the story. The analysis of the questionnaire showed that most of students agree to learn vocabulary by using Storytelling. The writer can conclude that Storytelling technique is effective and helpful to improve students' vocabulary mastery.

\section{BIBLIOGRAPHY}

Arisca, Elis. 2008. Improving the Students' Vocabulary Mastery through Storytelling at the Eighth Grade Students of SMPN 2 Kotagajah in the Academic Year of 2007/2008.

Unpublished Sarjana's Theses, of Teachers Training and Education: Muhammadiyah University of Surakarta.

Best, W. J. and Khan, V. J. 2002. Research in Education. New Delhi:Prentice-Hall.

Burn, P and Broman, B. L. 1975. The Language Arts In Childhood Education. Chicago: Rand Mc.Nally Collage. Publishing Company.

Ellis, G.1991. The Storytelling Handbook: A Guided for Primary Teacher of English. Harmondswath: Penguin Book.

Halimah, D.N. 2017. Improving Students' Vocabulary Mastery by Using Storytelling (A Classroom Action Research at the Seventh Grade of SMP Ta'mirul Islam Surakarta in the Academic Year of 2016/2017). Unpublis hed Sarjana's Theses, of Teachers Training and Education: The State Islamic Institute of Surakarta.

Hatch, E and Brown, C. 1995. Vocabulary, Semantic, and Language Education. New York: Cambridge University.

Hiebert, E. \& Kamil, M. 2005. Teaching and Learning Vocabulary Perspective and Persistent Issues.London: Lawrence erbium associates, Publisher.

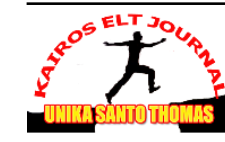


Kemmis, S. and McTaggart, R. 2010. The Action Research Planner (3 ${ }^{\text {rd }}$ Edition). Victoria: Deakin University Press.

Krashen, S. 1981. Second Language Acquisition and Second Language Learning. Oxford: Pregmanent.

Lewis, M. \& Hill, J. 1992. Practical Techniques for Teaching Language $\left(^{\text {th }}\right.$ Edition).Hove: Commercial Color Press

McDury, J and Alterio, M. 2003. The Effect of Storytelling on Children's Learning English Vocabulary: A case in Iran. International Research Journal of Applied and Basic Sciences, 5(1), 104.

Nunan, David. 1992. Research Methods in Language Teaching. New York: Oxford University.

Schmitt, Norbert. 1997. Teaching Vocabulary. New York: Cambridge Univers ity Press.

Somekh, Bridget. 2006. Action Research: A Methodology for Change and Development. New York: Open University Press.

Shepherd, J. 1990.Collage Vocabulary Skill. Hongton: Mifflin Company.

Stageberg, N.C \& Goodman, R.M. 1999. An Introductory English Grammar. Fort Worth, TX: Harcourt College Publishers.

Taylor, E. 2000. Using Folktales. Cambrige: Cambridge University.

Thornburry, Scott. 2002. How to Teach Vocabulary. London: Pearson Education Limited.

Ur, P. 1996. A Course In Language Teaching. Melbourne: Cambridge University. 